\title{
Emotional design and its contributions to digital educational technology in health and nursing: integrative review
}

\author{
Design emocional e as suas contribuiçóes para a tecnologia educacional digital na saúde e \\ na enfermagem: revisão integrativa \\ Diseño emocional y sus contribuciones a la tecnología educativa digital en la salud y la \\ enfermería: revisión integradora \\ Luciana Mara Monti Fonseca*; Min Lun Tsai**; Danielle Monteiro Vilela Dias***; Carmen Garcinda Silvan \\ Scochi****; Ananda Maria Fernandes*****; José Carlos Amado Martins******; Manuel Alves Rodrigues*******
}

\begin{abstract}
Context: In the use of digital technology educational, besides of the functionality and usability, the emotional aspects for human satisfaction gains importance.

Objectives: To identify the contributions of the emotional design in educational technology for health and nursing.

Methodology: Integrative review through the LILACS, MEDLINE, PsycINFO and IndexPsi databases, from 2001 to 2011, searching publications on design, emotion, educational technology, health and nursing. Protocol review and thematic categorization were performed.

Results: Five primary studies were considered from the inclusion and exclusion criteria, in which $40 \%$ of them were classified as very good and 60\% good, according the agree and ability to respond to the main question, but most have low level of evidence. Qualitative meta-synthesis of the raised the design of technology helps in motivating student and learning feedback, allows interaction between students and learning facilitators and enhances the link between theory and practice.

Conclusion: Although important and promising, the analysis and discussion of emotional design in educational technology is still incipient in health and nursing, with research gaps.
\end{abstract}

Keywords: computer-assisted instruction; design; emotion; educational technology.

\section{Resumo}

Contexto: Na educação, as tecnologias digitais têm elevada utilidade. Entre outros, o design emocional é central na satisfação do utilizador. Objetivos: Identificar as contribuições do design emocional na tecnologia educacional para saúde e enfermagem.

Metodologia: Revisão integrativa nas bases LILACS, MEDLINE, PsycINFO e IndexPsi, de 2001 a 2011, procurando publicações sobre design, emoção, tecnologia educacional, saúde e enfermagem. Construído o protocolo da revisão e realizada a categorização temática.

Resultados: Pelos critérios de inclusão e exclusão foram considerados 5 estudos primários, em que $40 \%$ destes foram classificados como muito bons e $60 \%$ bons, de acordo com a capacidade de responder à questão norteadora. A maioria apresenta baixo nível de evidência. Da metassíntese qualitativa levantamos que o design da tecnologia auxilia na motivação do estudante e feedback da aprendizagem, possibilita a interação entre os estudantes e mediadores da aprendizagem e potencializa a ligação entre teoria e prática.

Conclusão: Apesar de importante, a análise e discussão acerca do design emocional na tecnologia educacional é incipiente na saúde e enfermagem, sendo fundamental mais investigação.

Palavras-chave: instrução por computador; design; emoção; tecnologia educacional.

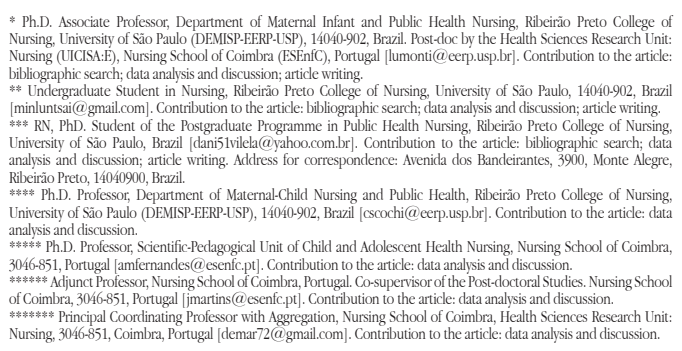

\section{Resumen}

Contexto: En la educación, las tecnologías digitales tienen una elevada utilidad. Entre otros, el diseño emocional es central para satisfacer al usuario.

Objetivos: Identificar las contribuciones del diseño emocional en la tecnología educativa para la salud y la enfermería.

Metodología: Revisión integradora en las bases de datos LILACS, MEDLINE, PsycINFO y IndexPsi, de 2001 a 2011, buscando las publicaciones sobre diseño, emoción, tecnología educativa, salud y enfermería. Se construyeron el protocolo de revisión y la categorización temática.

Resultados: Por los criterios de inclusión y exclusión, se consideraron 5 estudios primarios, en los cuales el 40\% de ellos fueron clasificados como muy buenos y el $60 \%$ como buenos, de acuerdo con su capacidad para responder a la cuestión principal. La mayoría tiene bajo nivel de evidencia. De la metasíntesis cualitativa planteamos que el diseño de la tecnología mejora la motivación de los estudiantes en el aprendizaje y la retroalimentación, permite la interacción entre los estudiantes y los facilitadores de aprendizaje y potencia la relación entre la teoría y la práctica.

Conclusión: A pesar de ser importante, el análisis y la discusión del diseño emocional en la tecnología educativa, con lagunas en la investigación, es aún incipiente en la salud y la enfermería, por lo que es fundamental desarrollar más la investigación.

Palabras clave: enseñanza por computadora; diseño; emoción: tecnología educacional.

Received for publication: 22.01 .14

Accepted for publication: 07.05 .15 


\section{Introduction}

Educational technologies are important in the teaching-learning process due to their interactivity (user's control and independence in information selection and work pace), the integration of several media formats (information presented in different ways, thus meeting different learning styles and preferences), and the nonlinearity of information (the user moves around the software through associations between pieces of information, which indicates similarities with the natural learning process (Struchiner \& Ricciardi, 2003).

Digital technology is considered as all products with a technical-scientific purpose, with greater or lesser potential for interaction, to be used in laptops, tablets, PCs or smartphones.

Thus, we believe that educational technologies should be used by the student with the purpose of building his/her own knowledge, transforming and using them as a dynamic and inventive resource. The educator can guide the work in such a way that the student uses technology not only to receive information, but also to think and create.

Thus, we have observed that the use of this technology allows for a more dynamic teaching-learning process of students, health professionals and users, offering a new way of teaching which is more individualised, but also collective and participatory. This new way of teaching respects each individual's learning pace and has the potential to assist in the provision of highquality and more humanised education and care.

With the purpose of helping educational technologies achieve this objective, we emphasise the issue of user satisfaction, in which the study of the emotional dimension of educational technologies, although still scarce, has been gaining importance.

Human satisfaction has prompted studies in the area of design to overcome their traditional theoretical-practical limits, leading it into a new reality. Thus, significant efforts have been made to increase knowledge on the individual, the context, and the relations with the product, with a view to understanding the emotional meaning of the relations between products and people, which implies going beyond the reductionist product-tool idea (Scolari, 2008).

According to the International Council of Societies of Industrial Design (ICSID, 2008), design is a creative activity whose aim is to establish the multi- faceted qualities of objects, processes, services and their systems. Therefore, design is the key factor of humanisation and innovation of technologies. Emotional design means using these characteristics of technology to awaken emotions in users with a welldefined purpose.

This new approach has the potential to improve the educational technologies that have been developed in different areas of knowledge to support the teachinglearning process. In health, the use and application of emotional design is still practically inexistent.

In Brazilian nursing, the development of computermediated courses is currently a growing trend linked to universities with research projects mainly targeting undergraduate education and users' health education (Padalino \& Peres, 2002). However, the influence, contributions, and impact of emotional design are still rarely considered in the construction of these educational technologies in the health area.

Thus, with the purpose of identifying emotional design and its contributions to educational technology in health in national and international journals, this study was conducted to identify the contributions of emotional design to digital educational technology in the areas of health and nursing.

\section{Methodological Procedures of Integrative Review}

This review followed the three steps of an integrative literature review, i.e. planning, conducting and reporting the review (Oates \& Capper, 2009). The protocol was reviewed by two experts in systematic review and their suggestions were included (Kitchenham, 2007). The guiding question for the review was formulated: What are the contributions of emotional design to digital educational technology in health?

In the question raised in this study, the PIO elements are the following: population (P), the digital educational technologies; intervention (I), emotional design; and the outcome $(\mathrm{O})$, the contributions. Comparison and context, as in the study of Costa and Cardoso (2010), were not used since the study was neither conducted in a specific context nor meant to be compared to the analysed studies (Kitchenham, 2007).

The following search terms were defined based on the population, the intervention, and the outcomes (PIO): 
interface, utilizador (user), computador (computer), emoções (emotions), materiais de ensino (teaching materials), tecnologia educacional (educational technology), recursos audiovisuais (audiovisual resources), saúde (health) and desenbo (design). Search for primary studies were performed using a combination of the terms in the following databases: LILACS, MEDLINE, PsycINFO, and IndexPsi.

The studies included in this review met the following criteria: studies that addressed emotional design related to digital educational technology in health and nursing, in Portuguese, English or Spanish, and published between 2000 and 2011. After analysis of the title, keywords, and abstract, the following exclusion criteria were applied: studies that were not available in an open access form for consultation; studies that did not answer the guiding question; and repeated studies.

According to Kitchenham (2007), while conducting the review and after the protocol is set, the selection of primary studies can start and, subsequently, data extraction and analysis. Inclusion and exclusion criteria were applied in study selection. Initial searches return a large number of irrelevant studies, and studies that do not answer the research question or address the topic, which are excluded. For the selection of primary studies, two researchers initially search for potential studies and each researcher draws up a list with his/her selection. Both lists are then compared and combined to achieve a single list of potential candidates. Based on this list, all studies are assessed by two or more researchers. After abstract reading and application of the inclusion and exclusion criteria, a final list of primary studies is made. The included studies, as well as the excluded studies and the respective exclusion criterion are documented in specific forms. Subsequently, each primary study is read, data are extracted using forms, and the relevance of the study to answer the guiding question is analysed.

The coded studies (E1 to E5) were assessed in terms of implementation (type of study and design), but, especially, in terms of results, i.e. if the study answered the guiding question of this study. Thus, the studies were assessed on a Likert-type scale with levels of agreement and disagreement. The studies were scored from 4, strongly agree (the study included in the text the criteria that answered the guiding question in full); 3 , partially agree (the study partially answered the question); 2, neutral (it was not clear if the study answered the question or not); 1, partially disagree (the study did not met the criteria included in the guiding question); to 0 , strongly disagree (nothing in the study answered the guiding question). According to the classification by Beecham, Baddoo, Hall, Robinson, and Sharp (2007), the studies can be divided into five levels according to their ability to answer the guiding question: $>86 \%$, excellent; $66-85 \%$, very good; $46-65 \%$, good; $26-45 \%$, fair; and $<26 \%$, poor.

In addition to the ability to answer the guiding question, we believe that it is important to identify the level of evidence of each study. Thus, we consulted the Joanna Briggs Institute (JBI). In 2003-2004, the JBI used the levels of evidence of the Australian National Health \& Medical Research Council - NHMRC Development, implementation and evaluation for clinical practice guidelines published in 1999. These levels of validity for recommendations and clinical guidelines focus, understandably, on treatment effectiveness. As the JBI has a broader definition of evidence, a more inclusive approach was used for the development and classification of levels of evidence and the implications for practice. It currently uses the following levels of evidence shown in the table below (Joanna Briggs Institute, 2012) and used in this study:

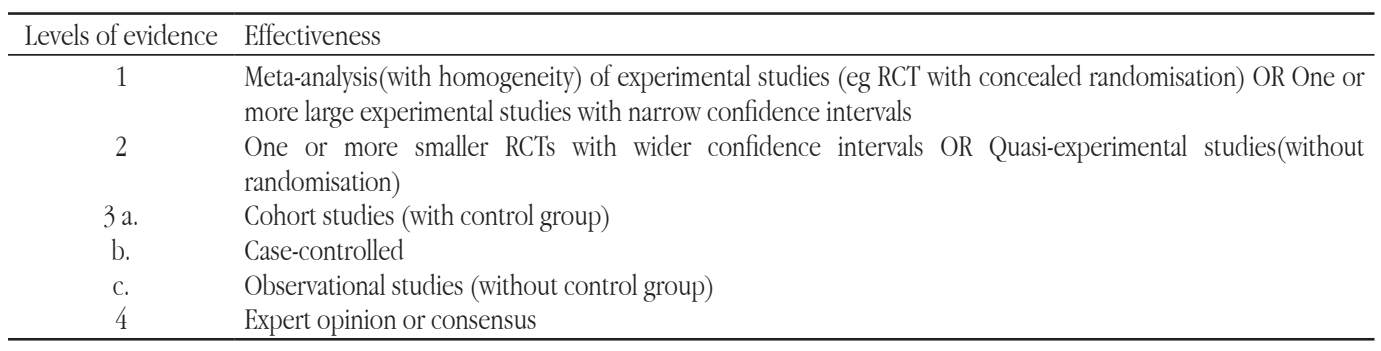

Figure 1. Levels of evidence X effectiveness of the study (JBI, 2012). 
Data extracted from the studies were organised into a table to facilitate the visualisation and comparison of the information of each study. In this process, the primary studies were read in full, and specific excerpts that provided important information to answer the guiding question were selected, with a view to metasynthesis.

Metasynthesis entails the translation and analysis of original data, looking for new interpretations, encompassing and distilling the meanings in studies that are part of the sample (Zimmer, 2006).

\section{Results and Interpretation}

The integrative review followed the protocol. Based on the sources and combinations of terms, the bibliographic search retrieved 139 studies. Of these 139 studies, 109 studies (78.4\%) that had been considered potentially relevant in the first selection were excluded mainly for not answering the guiding question. Twenty-two (15.9\%) studies were also excluded for lack of access to the article and abstract, and three (2.1\%) for lack of access to full text. Thus, five (3.6\%) studies were included in this review.

Of the 109 articles that did not answer the guiding question, 51 (46.8\%) were studies in which the design was more focused on the usability of technological interfaces and did not associate emotion with the interface of digital educational technology, 47 (43.1\%) were articles that addressed the issue of design, but did not associate it with educational technology, and 11 (10.1\%) were studies that showed the use of technology in education without considering aspects related to design. Many of these latter studies showed the use of technologies in case of depression and anxiety among professionals and users.

Of the 139 studies, six (4.3\%) were found in the LILACS database. In three (50\%) of these studies, the abstract was not available, and three (50\%) did not address the theme, covering the use of digital technology in education without associating it with design.

A total of 132 (94.9\%) of the 139 studies were found in MEDLINE. Of these, 20 (15.2\%) had no abstract available, one (0.7\%) was not available in full-text, and 106 (80.3\%) did not address the theme. Five (3.8\%) articles remained to be analysed.

Of the 106 articles found in MEDLINE database that did not address the theme, 51 (48.1\%) articles were related to studies that address design, but without associating the emotion with the studied technology; 47 (44.3\%) studies reported the design without associating it with the educational technology; and eight (7.4\%) articles showed the use of technology in education without associating it with the design.

One (0.8\%) study was found in IndexPsy. However, its abstract was not available. No article was found in the PsycINFO database.

Therefore, the five articles analysed in our study were found in the MEDLINE database. Based on the analysis of the five primary studies, a table was built including the coded studies, year and country of publication, type of study, level of evidence, and results, as shown in Table 1.

Table 1

Distribution of articles on emotional design and its contributions to educational technology, according to authors, year, country, type of study, level of evidence, and results

\begin{tabular}{|c|c|c|c|c|}
\hline Study & Year/Country & Type of Study & $\begin{array}{l}\text { Level of } \\
\text { Evidence }\end{array}$ & Results \\
\hline $\begin{array}{l}\text { E1 (Reynolds, Harper, } \\
\text { Mason, Cox, \& Eaton) }\end{array}$ & 2008/England & Reflection & 4 & $\begin{array}{l}\text { Digital technology provides improvements by supplying } \\
\text { animation and live images that can motivate the student. }\end{array}$ \\
\hline E2 (Griffin) & $\begin{array}{l}\text { 2003/United } \\
\text { States }\end{array}$ & Descriptive & $3 c$ & $\begin{array}{l}\text { Technology in virtual environments increases the } \\
\text { student's ability to transform the received information } \\
\text { into knowledge, enhancing the learning experiences. }\end{array}$ \\
\hline $\begin{array}{l}\text { E3 (Kamin, O'Sulivan, } \\
\text { Deterding, \& Younger) }\end{array}$ & $\begin{array}{l}\text { 2003/United } \\
\text { States }\end{array}$ & Exploratory & $3 a$ & $\begin{array}{l}\text { Students using educational technologies engaged more } \\
\text { in critical thinking. }\end{array}$ \\
\hline E4 (Rawson \& Quinlan) & $\begin{array}{l}\text { 2002/United } \\
\text { States }\end{array}$ & $\begin{array}{l}\text { Experimental } \\
\text { randomised }\end{array}$ & 2 & $\begin{array}{l}\text { The use of technology led to a greater understanding } \\
\text { of the theme through design to build, test and rebuild } \\
\text { content explanation. }\end{array}$ \\
\hline $\begin{array}{l}\text { E5 (Buzzell, Chamberlain, } \\
\text { \& Pintauro) }\end{array}$ & $\begin{array}{l}\text { 2002/United } \\
\text { States }\end{array}$ & $\begin{array}{l}\text { Experimental } \\
\text { non- } \\
\text { randomised }\end{array}$ & 2 & $\begin{array}{l}\text { Educational technologies have the same potential in } \\
\text { higher education as traditional classes. However, the } \\
\text { student has a more proactive attitude towards multimedia. }\end{array}$ \\
\hline
\end{tabular}


Of the five studies considered, two (40\%) were published in 2002, two (40\%) in 2003, and one (20\%) was carried out in 2008.

As to the type of study, one is a descriptive study (opinion), one is a reflection study (opinion), one is an exploratory study, one is a pre/post-test quasiexperimental study, and another one is an original research study.

As regards the level of evidence, studies E1 is in level 4, E2 in level 3c, E3 in level 3a, and E4 and E5 in level
2 , which represents a low level of evidence for most of them. Even the studies with high level of evidence did not exclusively assess the design of educational technology or the emotion it evokes, focusing on learning and referring to design and emotion as responsible factors.

The classification according to the score assigned taking into account the relevance of each study to answer the guiding question is shown in Table 2 .

Table 2

Classification of primary studies regarding their ability to answer the guiding question

\begin{tabular}{|c|c|c|c|c|c|c|}
\hline & $\begin{array}{l}\text { Poor } \\
<26 \%\end{array}$ & $\begin{array}{c}\text { Fair } \\
26-45 \%\end{array}$ & $\begin{array}{l}\text { Good } \\
46-65 \%\end{array}$ & $\begin{array}{c}\text { Very good } \\
66-85 \%\end{array}$ & $\begin{array}{c}\text { Excellent } \\
>86 \%\end{array}$ & Total \\
\hline $\begin{array}{c}\text { Number of primary } \\
\text { studies }\end{array}$ & & & 3 & 2 & & 5 \\
\hline$\%$ & & & $60 \%$ & $40 \%$ & & $100 \%$ \\
\hline
\end{tabular}

As can be seen, none of the studies was considered poor or fair, and three studies were classified as Good and two as Very Good. Therefore, despite the limited number of studies found for analysis, they are closely related to the topic under study, adequately answering the research question.

The qualitative metasynthesis of the results from the five studies concluded that the design of the technology (a) contributes to the students' motivation and learning feedback, (b) enables the interaction between students and learning facilitators, and (c) enhances the connection between theory and practice.

\section{The design of the technology contributes to the students' motivation and learning feedback}

Courses based on educational technology should be student-centred, not teacher-centred. An advantage of this medium is that course creators can focus on the students' needs, thinking about the best way for them to feel supported. The creative, innovative process is to make the student feel challenged, motivating him/her to use the technology. Thus, educational technologies have sought to provide a more personalised student experience by incorporating more motivational, less rigid and more social tools, and considering students as co-creators (Reynolds, Harper, Mason, Cox, \& Eaton, 2008).

The educational technology created was considered interesting, easy-to-use and easy-to-understand, attractive, engaging students and keeping their interest during the course. They mention that the choice of colours and the layout is easy to read and follow, contributing to motivate users (Reynolds et al., 2008).

Contents that are difficult to learn can demotivate students. The learning of these contents through technology has demonstrated a higher level of understanding by the students who feel more involved in the learning process. Students' engagement in their own education is the key to better learning, and technology has presented new ways to involve them (Griffin, 2003).

In computer simulation of a clinical situation in a virtual world, the students reported that they felt challenged and with enough time to analyse and build a deeper meaning (Kamin, O'Sullivan, Deterding, \& Youger, 2003).

The students felt motivated by using the educational technology and replied that they wanted to use the technology again to repeat and review the existing clinical cases (Rawson \& Quinlan, 2002).

A study that compared the effectiveness of lectures with the use of educational technology found no statistical difference in students' learning, as both methods were considered to be effective. However, in addition to performance, they observed an indicator of perceived ease of learning in the group that used the technology, which was a more positive attitude by the students. This suggests that multimedia 
methods have added a measure of relevance to the topic not present in the lectures. This may be due to the design of the technology, the virtual nature of interactive animations, combined with videos of actual procedures (Buzzell, Chamberlain, \& Pintauro, 2002).

The students felt more motivated when the technology helped them to build a practical understanding of the contents. They realised that the tool aimed at meaningful learning and focused on an understanding of the clinical problems rather than on memorisation (Rawson \& Quinlan, 2002).

Repetition and feedback reinforcement improve learning. The educational technology can provide a more simple feedback, such as affirming the student's choice, or a more extensive feedback, by providing information that address commonly held misconceptions (Rawson \& Quinlan, 2002).

The design of an educational technology should start with the outline of the learning objectives, contents, and materials, and then a step-by-step approach of logical progression to learning, interspersed with tests for feedback on what was taught (Reynolds et al., 2008).

The confidential system of grades and evaluations provided by technology and the possibility to contact the teacher was considered an important form of motivation and feedback of students' learning (Griffin, 2003).

An appropriate technology needs to provide a clear structure so that users will feel that they are making progresses in terms of learning (Reynolds et al., 2008). The educational technology provides feedback not only to the student, but in particular to the teacher on whether the students are understanding the contents and the process is aligned with the learning objectives. Another form of valuable feedback to the teacher is the statistical data concerning how students use the technology and its effectiveness (Griffin, 2003).

Although technological advances will continue to offer teachers new ways of teaching, the effectiveness of technology will always depend on its appropriate use, as well as on positive skills and attitudes towards technology. A well-planned and enthusiastic application of technology by the teacher will undoubtedly instil students to use technologies (Griffin, 2003).

One of the real advantages to the use of educational technology is to free time for the teachers to devote to the higher levels of cognitive learning of their students, such as synthesis, analysis, and evaluation (Buzzell et al., 2002).

\section{The design of the technology enables the interaction between students and learning facilitators}

With the move to a digital age of paperless classrooms, educational technologies have become valuable tools, providing students with easy access to all relevant documents and information that promote a critical and reflexive learning and discussions outside of the classroom, such as through interactive forums, e-mail, and chat (Griffin, 2003).

Web-based courses should consider face-to-face and online interaction moments, and technologies should consider different forms of interaction. Both of them have an impact on education (Reynolds et al., 2008). Software programmes allow students to access the contents when they are ready for it and at their own pace, as well as to discuss new ideas and perceptions with peers. The design of the technology should encourage students to work in pairs, even if they complete the program independently, by promoting collaboration and encouraging a slow and thoughtful progression of learning (Rawson \& Quinlan, 2002).

The students considered that the ability to quickly access information that they need to acquire new knowledge, as well as the ability to interact outside the classroom, given the difficulty of discussion during formal classes and lectures, are significant parts of the technology. In addition, many of the students stated that they were unwilling to speak during lectures or classroom discussions, but that the virtual discussion on these contents became exciting and lasted for several days, engaging the students in discussions and improving their ability to convey their knowledge (Griffin, 2003).

The supply of animation, dynamic images, and videos can have a greater impact than photos and text materials. The media can improve the message between technology, students, and tutors. The design can replicate the personal involvement of a face-toface classroom session. Learning often occurs in the interaction between students and teachers, involving content traffic and discussion via technology (Reynolds et al., 2008).

Learning occurs during the group's collaborative discussion, so the technologies' design should 
promote the asynchronous discussion between students and teachers, so that they write their thoughts and arguments rather than speak them. As a result of the reflective and explicit nature of writing, the virtual modality may have inherent advantages over speech in learning (Kamin et al., 2003).

\section{The design of the technology enhances the connection between theory and practice}

The new generation of students, born in the 1980s, has been described as the 'net generation'. They have grown up in a digital world and are today's graduates who feel more comfortable learning using the communication technologies that facilitate social networking and collective intelligence (Reynolds et al., 2008).

Students and teachers reported that there are contents difficult to learn and complex to teach, as they may involve dynamic aspects related to motion, changes occurring over time, or the complex integration of multiple events. The multimedia methods (text, graphics, sounds, animations, and images) have improved the presentation of these contents, creating a true learning experience for the student, and leading to a greater understanding (Griffin, 2003).

By using real cases for discussion, an American study has achieved greater success in learning using educational technologies, since the modality of virtual case allowed for a better visualisation of the case, with simulated dynamic images. Students could control their learning of the clinical situation, review the respective images, and reflect in a more indepth way in group discussions than in the other two modalities of education that did not present the case so realistically (Kamin et al., 2003).

Historically, there are difficult subjects to learn and computer programs can provide additional support for students. Technologies provide students with an environment that retains the complexity of clinical cases they will encounter in their future professional lives. Students considered that the design characteristics of the technology interface were able to evoke the realism of the clinical situations (Rawson \& Quinlan, 2002).

Computer technology is likely to play an increasingly important role in teaching and is viewed as having the potential for transforming both teaching and learning, thus improving students' understanding. A computer program designed for undergraduate students to more easily and quickly understand and assimilate subjects difficult to understand presents real clinical cases for them to build a more meaningful knowledge. It was concluded that the interface gave students understanding and encouragement, contributing significantly to their self-confidence about the topic (Rawson \& Quinlan, 2002).

There has been a rapid introduction, dissemination, and use of information technologies, and given the computer revolution and consequent extension of computational resources in education, the computer is being used not as a machine but as an aid in the teaching-learning process (Moran, 2006).

Educational technologies have increased the interest in user-centred design, with a shift of focus from behaviour and cognition to the users' affective experiences in their interaction with the product (Desmet \& Hekkert, 2007).

With a view to human satisfaction, a growing number of studies in the area of design are concerned with the emotional meaning of the relations between technology and people. In this new field, despite the relevant contributions, no consensus has yet been reached as to its designation, thus there are derivations of the English terms, such as Emotion Design (Buccini \& Padovani, 2005), and also literal translations of the terms such as Design Emocional and Design e Emoção (Damazio, 2005).

The concept of emotional design aims to demonstrate that it is possible to establish a relationship with the user, as well as analyse and decide on the meanings that should be triggered for that to happen. Emotional design combines aesthetics and functionality to design a product that appeals to the users' subjective emotions, motivating them towards action. The brain can be positively or negatively stimulated on three levels: visceral design (the user is awakened by the objects' appearance/aesthetics, in an emotional and instinctive impact, thus triggering a corresponding action), behavioural design (it focuses on the user's experience with the product, the usability and performance offered by product, as well as the user's needs), and reflective design (stimulated by the meaning of a product and its use).

Positive emotions evoked by the design of educational technologies' interface facilitate the cognitive process, and improve learning, performance, and satisfaction. Despite the possibilities of emotional design as promotor of the use of digital technologies in 
education, the production of knowledge with this approach in the health area is still scarce, as well as the development of studies with high level of evidence.

\section{Conclusion}

Literature reviews may help identify the progress made in terms of knowledge development and also guide new research projects. This study demonstrates that there is a lack of studies with high level of evidence on the importance of emotional design in educational technology in health and nursing. However, it covers an area of study that, despite incipient, has been considered promising as to its contribution to the digital user-technology interaction in education, health, and nursing.

The study demonstrates that emotional design combined with the digital educational technology in health contribute to increase the students' motivation and learning feedback, allowing for an interaction between students and learning facilitators and enhancing the connection between theory and practice.

Despite the limited number of articles found in this study, which is a limitation of this review, these studies have shown strong and important indicators and a significant development in the areas of Design and Computer Engineering, which can be translated into innovation and contribution for research and education in the health area.

We believe that we have contributed to inspire research on emotional design of educational technology in health and nursing. We hope that this study will arouse the interest of health professionals to include this important subject in research projects, addressing the theme of design, emotion, and educational technology, with the purpose of increasing knowledge and the use of digital technology in education, with emotionally integrated users.

We hope that this study will be used as a reliable guide in other studies of this nature.

\section{References}

Beecham, S., Baddoo, N., Hall, T., Robinson, H., \& Sharp, H. (2008). Motivation in software engineering: A systematic literature review. Information and Software Technology, 50(9-10), 860-878. doi: 10.1016/j.infsof.2007.09.004
Buccini, M., \& Padovani, S. (2005). Uma introdução ao design experiencial. Estudos em Design, 13(2), 63-75.

Buzzell, P. R., Chamberlain, V. M., \& Pintauro, S. J. (2002). The effectiveness of webbased, multimedia tutorials for teaching methods of human body composition 17 analysis. Advances in Physiology Education, 26(1), 21-29. doi: 10.1152/ advan.00007.2001

Costa, C. R., \& Cardoso, A. V. (2010). Aprendizagem científica e tecnológica no ensino: Uma experiência de design de material didático em 3D. Revista Latino-Americana de Enfermagem, 17(5), 147-155.

Damazio, V. (2005). Artefatos de memória da vida cotidiana: Um olhar interdisciplinar sobre as coisas que fazem bem lembrar (Tese de doutoramento não publicada). Universidade Estadual do Rio de Janeiro, Brasil

Desmet, P., \& Hekkert, P. (2007). Framework of product experience. International Journal of Design, 1(1), 57-66.

Griffin, J. D. (2003). Technology in the teaching of neuroscience: Enhanced student learning. Advances in Physiology Education, 27(3), 146-155. doi: 10.1152/advan.00059.2002

International Council of Societies of Industrial Design. (2008). Definition of desing. Retrieved from http://www. icsid.org/ about/about/articles31.htm

Joanna Briggs Institute. (2012). Education and Learnning. Retrieved from http//www.joannabriggs.org/

Kamin, C., O'sullivan, P., Deterding, R., \& Youger, M. (2003). A comparison of critical thinking in groups of third-year medical students in text, video, and virtual PBL case modalities. Academic Medicine, 78(2), 204- 211.

Kitchenham, B. (2007). Procedures for Performing Systematic Reviews. Joint Technical Report, TR/SE-0401 and NICTA 0400011T.1, Keele University. Retrieved from http://www.idi. ntnu.no/emner/empse/papers/kitchenham_2004.pdf

Moran, J. M., Macrae, C. N., Heatherton, T. F., Wyland, C. L., \& Kelley, W. M. (2006). Neuromatical evidence for distinct cognitive and affective components of self. Journal of Cognitive Neuroscience, 18(9), 1586-1594. doi: 10.1162/ jocn.2006.18.9.1586

Oates, J. B., \& Capper G. (2009). Using systematic reviews and evidence-based software engineering with masters students. In Proceedings of the International Conference on Evaluation \& Assessment in Software Engineering, Durbam University, United Kingdom, 20-21 April 2009 (pp. 79-87). Swinton, United Kingdom: British Computer Society.

Padalino, Y., \& Peres, H. H. (2002). Elearning: Estudo comparativo da apreensão do conhecimento entre enfermeiros. Revista Latino-Americana de Enfermagem, 15(3), 397-403. doi: 10.1590/S0104-11692007000300006

Rawson, R. E., \& Quinlan, K. M. (2002). Evaluation of a computerbased approach to teaching acid/base physiology. Advances in Physiology Education, 26(2), 85-97. doi: 10.1152/ advan.00042.2001 
Reynolds, P. A., Harper, J., Mason, R., Cox, M. J., \& Eaton, K. (2008). An intricate web : Designing and authoring a webbased course. British Dental Journal, 204(9), 519-524. doi: 10.1038/sj.bdj.2008.351

Scolari, S. H. (2008). Design e emoção : Um modelo de círculos de referências de emoções em produtos (Dissertação de mestrado não publicada). Universidade Estadual Paulista, Faculdade de Arquitetura, Artes e Comunicação, São Paulo, Brasil.
Struchiner, M., \& Ricciardi, R. M. (2003). Princípios, modelos e tecnologias de informação e comunicação em processos educativos das ciências biomédicas e da saúde. Revista Rio de Janeiro, 11(5), 56-63.

Zimmer L. (2006). Qualitative meta-synthesis: A question of dialoging with texts. Journal of Advanced Nursing, 53(3), 311-18. doi: 10.1111/j.1365-2648.2006.03721.x 
